Удк 657.1

JEL Classification: M4

DOI: https://doi.org/10.35774/visnyk2020.01.187

\title{
ОЛЬГа ПУГАЧЕНКО,
}

кандидат економічних наук, доцент, доцент кафедри аудиту та оподаткування,

Центральноукраїнський національний технічний університет, м. Кропивницький, пр. Університетський 8, ауд. 562, 25000, Україна

E-mail: pugachenkoolga@gmail.com

ORCID ID 0000-0002-2253-050X

\section{УДОСКОНАЛЕННЯ ОРГАНІЗАЦІЇ ПРОЦЕСУ МАТЕРІАЛЬНОГО ЗАБЕЗПЕЧЕННЯ ЧЕРЕЗ ІНТЕГРАЦІЮ ОБЛІКУ 3 ІНШИМИ ФУНКЦІЯМИ УПРАВЛІННЯ}

Пугаченко О. Удосконалення організації процесу матеріального забезпечення через інтеграцію обліку з іншими функціями управління. Вісник Тернопільського національного економічного університету. 2020. Вип. 1. C. 187-199. DOI: https://doi. org/10.35774/visnyk2020.01.187

Puhachenko O. (2020). Udoskonalennia orhanizatsii protsesu materialnoho zabezpechennia cherez intehratsiiu obliku z inshymy funktsiiamy upravlinnia [Improvement of the process of material support through integration of accounting with other managerial functions]. The Herald of Ternopil National Economic University, Vol. 1. P. 187-199. DOI: https://doi.org/10.35774/visnyk2020.01.187

\section{Анотація}

Вступ. Облік та його органічний зв'язок з іншими фуункціями управління (планування, контролю, економічного аналізу, регулювання, стимулювання) й узагальнення процесу виробництва та розподілу матеріальних благ стає важливим важелем активної діяльності підприємства, тому його інтеграція з іншими фуункціями управління є цілком логічною і закономірною. У статті представлено напрямки вдосконалення організації процесу матеріального забезпечення, що сприяють посиленню взаємозв'язку обліку з іншими функціями управління.

Mema i методи дослідження. Мета статmі - окреслення рекомендацій із вдосконалення процесу матеріального забезпечення через інтеграцію обліку з іншими функціями управління. Для досягнення вказаної мети запропоновано авторське бачення алгоритму вирішення основних завдань економічного сектору служби матеріального забезпечення. Дослідження базується на методах аналізу, узагальнення та групування. У процесі визначення конкретних завдань

(C) Ольга Пугаченко, 2020. 
в економічному секторі служби матеріального забезпечення було застосовано метод графрічного представлення.

Результати. Запропоновано фррагмент організаційної структури, що інтегрує інформаційні та оперативно-виробничі функції управління процесами матеріального забезпечення, у якій відділ матеріального забезпечення складається із секторів закупівель, зберігання і руху й економічного сектору. Для вирішення основних завдань служби матеріального забезпечення в економічному секторі розроблено та наведено такі схеми: організації процесу встановлення норм матеріальних ресурсів; організації процесу планування потреб у матеріальних ресурсах; порядку поточного обліку надходження матеріальних ресурсів, їх переміщення $і$ видачі підрозділам та виявлення фрактичного стану виробничих запасів; організації нагляду, інвентаризацій і перманентного контролю за процесами матеріального забезпечення; порядку розробки заходів із більш раціонального використання матеріальних ресурсів.

Перспективи. Об’єктом наших майбутніх досліджень буде розробка рекомендацій з вдосконалення системи матеріального забезпечення окремих підприємств різних сфрер національної економіки із врахуванням впливу галузевих особливостей та специфіки виробничих процесів.

Ключові слова: облік; інтеграція; процес матеріального забезпечення; організація; фрункції управління; економічний сектор; завдання служби матеріального забезпечення.

Рис.: 6, Табл.: 1, бібл.: 13.

\section{Abstract}

Olga PUHACHENKO

IMPROVEMENT OF THE PROCESS OF MATERIAL SUPPORT THROUGH INTEGRATION OF ACCOUNTING WITH OTHER MANAGERIAL FUNCTIONS

Introduction. Accounting and its organic connection with other functions of management (planning, control, economic analysis, regulation, stimulation) and generalization of the process of production and distribution of material goods are becoming an important lever of the enterprise's activity, so its integration with other managerial functions is quite logical. The article presents ways to improve the organization of the material support process which help to strengthen the relationship of accounting with other managerial functions.

Purpose and Methods. The purpose of the article is to develop directions for improving the organization of the material support process for the integration of accounting with other managerial functions. In order to achieve this goal, an author's vision of an algorithm for solving the basic tasks of the material support service in the economic sector is proposed. The study is based on methods of analysis, generalization and grouping. Graphic representation method was applied in defining specific tasks in the economic sector of material support service.

Results. A fragment of the organizational structure, which integrates operationalproduction and information functions of managing the processes of material support, is proposed. In this organizational structure the material support department consists of the sectors of procurement, storage and movement and the economic sector. In order to 
solve the basic tasks of the material support service in the economic sector, the following has been developed and presented: a scheme for organizing the process of establishing the standards of material resources; a scheme for organizing the process of planning the material resources need; the scheme of the order of current accounting of the receipt of material resources, their movement and issuance to units and the inventory detection; the scheme of organization of supervision, inventories and systematic control over the process of material support; a scheme of order of development of measures for more rational use of material resources.

Discussion. A prospect for further research is the development of proposals for improving the organization of processes and material support systems for enterprises of certain sectors of the national economy.

Keywords: accounting; integration; the process of material support; organization; management functions; the economic sector; the tasks of the material support service.

Fig.: 6, tabl.: 1, bibl.: 13.

Вступ (постановка проблеми). Служба матеріального забезпечення реалізує свої завдання через виконання своїх функцій, які пов'язані із внутрішнім і зовнішнім бізнессередовищем. Внутрішні - визначають взаємодію служби матеріально забезпечення з управлінським службами, виробничими підрозділами, лабораторією, фрінансовокомерційними структурами, відділами бухгалтерії (з розрахунків, праці та її оплати тощо), складами. Зовнішні функції характеризують відносини суб'єктів господарювання з органами державного управління, постачальниками та посередницько-збутовими підприємствами. Все це свідчить про необхідність розмежування відповідальності і повноважень окремих структурних підрозділів, встановлення дієвих взаємозв'язків із службою матеріального забезпечення та між собою, розмежування прав і обов'язків задля оптимізації всього процесу постачання.

Наразі, коли Україна перебуває у кризовихекономічнихіполітичних умовах, однією із основних проблем є розробка дієвого механізму процесів матеріального забезпечення як на рівні окремих суб'єктів господарювання, так і на загальнодержавному рівні. У процесі розробки ефективно дієвої системи матеріального забезпечення пріоритетним $€$ врахування кожної конкретної функції управління (планування, економічний аналіз, контроль, стимулювання, регулювання). Реалізація вказаних функцій без врахування інформаційних можливостей обліку буде ускладнена. Саме облікдопомагає встановити відхилення реального стану від бажаного, вчасно сигналізувати про невиконання запланованих індикаторів, аналізувати причини розбіжностей, розробляти ефективні заходи стимулювання й регулювання тощо.

Короткий огляд літератури. Про наявність взаємозв'язкуоблікузіншими функціями управління активно заявляв професор Б. І. Валуєв [1]. Інтерес до взаємозв'язку обліку з плануванням, аналізом, стимулюванням, контролем і регулюванням виявляли у своїх дисертаціях: Н. Я. Зарудна (на пивоварних підприємствах) [2]; О. Б. Пугаченко (у системі управління підприємствами хлібопекарної галузі) [3]; Н. А. Сиротенко (на кондитерських підприємствах) [4]; Г. В. Шурупов (у діяльності промислових підприємств) [5]. Варіанти вдосконалення системи управління матеріальним 
забезпеченням пропонують: Н. Балашук - шляхи покращення матеріально-технічного забезпечення в умовах ресурсних обмежень [6]; Н. М. Гуржій і І. С. Бебешко порядок моніторингу системи матеріального забезпечення на підприємствах харчової промисловості [7]; О. М. Гурин - методику формування раціональної структури системи матеріального забезпечення повітряного командування Повітряних сил Збройних сил України [8]; М. М. Дмитрик, О.І.Куліш, О. Д. Харіх - методику обліку процесів матеріального забезпечення у виробництві кондитерської продукції [9]; В. С. Кивлюк і Ю. О. Ганненко - напрямки удосконалення системи забезпечення матеріальними ресурсами для Збройних сил України [10]; М. М. Майборода - оцінку впливу матеріального забезпечення на ефективність виробництва зерна [11]; О. М. Розмислов та А. А. Мартинов - аналітичне забезпечення стратегічного управління матеріальними витратами підприємства [12] тощо. Незважаючи на те, що інтерес до розробки напрямків удосконалення системи матеріального забезпечення є постійним, все ще залишаються невирішені проблеми, які є об'єктом даної наукової розвідки.

Мета дослідження - окреслення рекомендацій із вдосконалення процесу матеріального забезпечення через інтеграцію обліку з іншими функціями управління. Для досягнення вказаної мети запропоновано авторське бачення алгоритму вирішення основних завдань економічного сектору служби матеріального забезпечення.

Основні результати дослідження. У табл. 1 представлено динаміку витрат на виробництво продукції (товарів, послуг) та питому вагу матеріальних витрат у загальній структурі виробничих витрат підприємств України з виготовлення хліба, хлібобулочних і борошняних виробів протягом 2012-2018 pp.

Таблиця 1

\section{Структура матеріальних витрат та витрат на оплату послуг,} використаних у виробництві у загальній сумі витрат на виробництво продукції (товарів, послуг) підприємств України з виробництва хліба, хлібобулочних і борошняних виробів протягом 2012-2018 рр.

\begin{tabular}{|c|c|c|c|c|}
\hline \multirow[t]{2}{*}{ Код за КВЕД-2010 } & \multirow[t]{2}{*}{ Роки } & \multirow{2}{*}{$\begin{array}{c}\text { Витрати на виробництво } \\
\text { продукції (товарів, послуг) } \\
\text { тис. грн }\end{array}$} & \multicolumn{2}{|c|}{\begin{tabular}{|c|} 
У тому числі матеріальні витрати та \\
витрати на оплату послуг, використані у \\
виробництві \\
\end{tabular}} \\
\hline & & & тис. грн & $\begin{array}{c}\text { y \% до загальних } \\
\text { витрат }\end{array}$ \\
\hline \multirow{7}{*}{$\begin{array}{c}10.7 \\
\text { «Виробництво } \\
\text { хліба, } \\
\text { хлібобулочних } \\
\text { і борошняних } \\
\text { виробів» }\end{array}$} & 2012 & 15262593,2 & 11534072,0 & 75,6 \\
\hline & 2013 & 16527339,6 & 12681010,2 & 76,7 \\
\hline & 2014 & 16817278,6 & 12979318,3 & 77,2 \\
\hline & 2015 & 22062662,5 & 18019373,6 & 81,7 \\
\hline & 2016 & 21771956,6 & 17635206,4 & 81,0 \\
\hline & 2017 & 22670711,3 & 17453950,7 & 77,0 \\
\hline & 2018 & 26855674,7 & 20298623,8 & 75,6 \\
\hline
\end{tabular}

Джерело: інформація з Офріційного сайту Державної служби статистики України. URL : http://www.ukrstat.gov.ua/ 
Згідно з інформацією з Офріційного сайту Державної служби статистики України та даними у табл. 1 найбільша питома вага $(\approx 75-82 \%)$ у загальній сумі витрати на виробництво продукції (товарів, послуг) підприємств України з виробництва хліба, хлібобулочних і борошняних виробів припадає на матеріальні витрати та витрати на оплату послуг, використаних у виробництві. Структура інших витрат, окрім матеріальних, така: витрати на оплату праці становлять $\approx 13-14 \%$; відрахування на

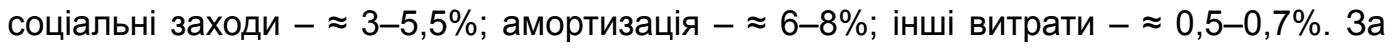
результатами 2018 р. простежується найменший відсоток саме матеріальних витрат у загальній структурі витрат (аналогічний показник був у 2012 р.); найбільша питома вага матеріальних витрат була у 2015 р. - 81,7\% та у 2016 р. - 81,0\%, що пояснюється нестабільністю національної валюти та збільшенням вартості придбання основної сировини для виробництва хліба, хлібобулочних і борошняних виробів. Все це ще раз підтверджує актуальність обраної теми дослідження та посилює нагальність розгляду шляхів удосконалення організації процесу матеріального забезпечення задля інтеграції обліку з іншими функціями управління.

Фрагмент організаційної структури, що інтегрує оперативно-виробничі та інформаційні функції управління процесами матеріального забезпечення, надано на рис. 1.

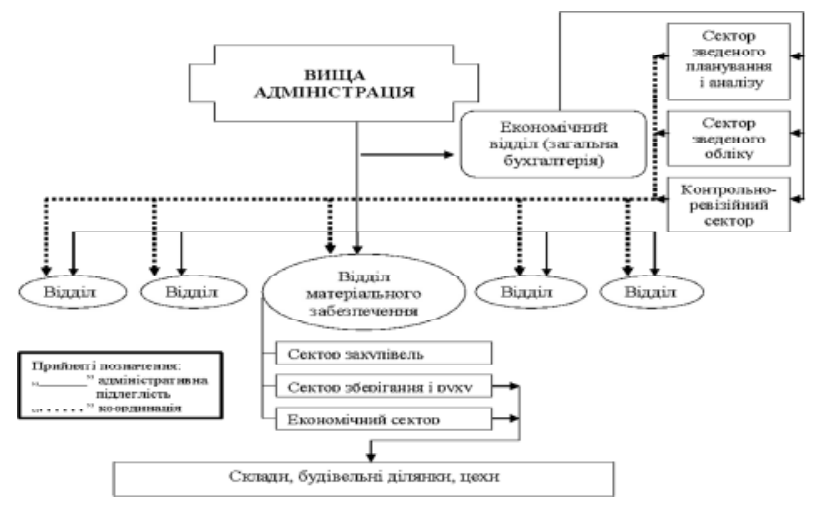

Рис. 1. Фрагмент організаційної структури, що інтегрує оперативно-виробничі та інформаційні функції управління процесами матеріального забезпечення Джерело: розроблено автором на підставі [1, с. 20; 5, с. 147]

3 рис. 1 видно, що функції обліку, планування, економічного аналізу, контролю, стимулювання й регулювання віднесено до повноважень економічного сектору. Служба матеріального забезпечення повинна задовольняти потреби у ресурсах, які необхідні та $є$ достатніми для забезпечення виробничо-господарської діяльності підприємства.

Обґрунтований склад завдань служби матеріального забезпечення окреслено у науковій праці [13, с. 66-67], але ми пропонуємо їх переформатувати в залежності від характеру конкретних процесів. На запропоновані сектори служби матеріального забезпечення покладаються такі повноваження: 
- сектор закупівель - виконання всієї діяльності з питань надходження запасів; здійснення оперативного обліку при надходженні матеріальних ресурсів; складання специфрікацій і замовлень на матеріальні ресурси; забезпечення всіх етапів діяльності ресурсами для здійснення виробничо-господарської програми; виявлення кількості й стану виробничих запасів за їх оприбуткування; організація оперативного контролю на етапі закупівель;

- сектор зберігання та руху - оперативний облік надходження матеріальних ресурсів на склади; виявлення кількості і стану виробничих запасів у коморах; організація розміщення, підготовки до видачі й видача матеріальних ресурсів відповідним підрозділам підприємства; оперативний контроль на всіх етапах зберігання запасів; забезпечення схоронності виробничих запасів;

- економічний сектор - визначення з іншими відділами необхідних норм запасів матеріальних ресурсів і доведення їх до відома всіх структурних підрозділів; встановлення наявності та стану виробничих запасів; планування потреби в матеріальних ресурсах для забезпечення безперервної роботи; поточний i оперативний облік надходження виробничих запасів, їх видача підрозділам; організація інвентаризації та нагляду; розробка заходів із більш ефективного використання матеріальних ресурсів; систематичний контроль усіх етапів процесу матеріального забезпечення.

Щодо кожного із вказаних завдань доцільно визначити заходи задля забезпечення їх виконання на конкретних етапах у певній послідовності. На основі цього потрібно розробити схему організації процесу матеріального забезпечення з чітким визначенням місця і ролі окремих управлінських фрункцій - планування, облік, економічний аналіз, контроль, стимулювання й регулювання.

Установлення разом із іншими відділами диференційованих і обґрунтованих розмірів запасів матеріальних ресурсів із доведенням їх до відома працівників складів визначається, як затвердження норм витрачання кожного виду запасів на конкретний вид продукції. Увагу слід приділяти узгодженості бачення всіх відділів (виробничо-технологічного, планово-економічного, технічного, фрінансового), які безпосередньо стосуються витрачання виробничих запасів за встановлення норм, оскільки ці ресурси використовуватимуть саме на місцях. Моніторинг інформації про фактичне витрачання ресурсів за попередній період, виявлення відхилень та аналіз їх причин допомагають переконатись у дієвості визначених норм у практичній діяльності. Експертні розрахунки реальних витрат сировини є важливим етапом встановлення норм запасів матеріальних ресурсів. Врахування технологічних особливостей виробничого процесу дає змогу (в разі виникнення потреби) уточнити та скоригувати затверджені норми. Наукове обґрунтування допомагає в регулюванні розміру запасів за наявності контролю за їх станом. Важливий етап - це доведення до відома працівників визначених норм, оскільки саме від їхньої свідомості та здійснюваних заходів контролю за ефективністю використання залежить фактичне дотримання нормативних величин. Схема організації процесу встановлення норм запасів наведена на рис. 2. 


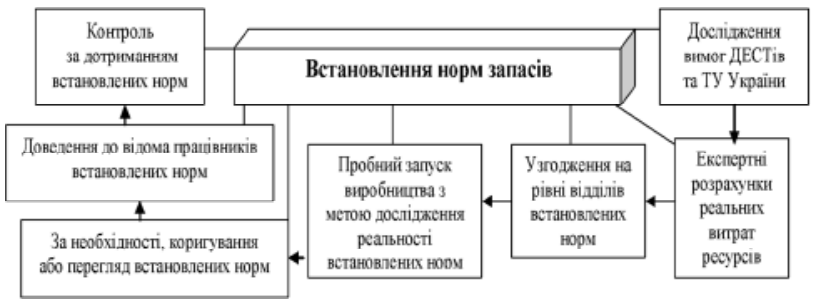

Рис. 2. Схема організації процесу встановлення норм матеріальних ресурсів Джерело: розроблено автором.

Для забезпечення безперервної роботи суб'єктів господарювання важливе значення має поточне та перспективне планування потреби в матеріальних ресурсах. Дослідження обсягів споживання конкретних видів продукції потрібне до складання виробничої програми. Розробка матеріальних балансів дає змогу визначити фактичну наявність кожного з видів запасів і встановити потребу. Визначення нормативних показників потреби виробничих запасів згідно з ДЕСТамт і Технічними умовами допомагає з'ясувати кількісні та якісні характеристики необхідних для виконання виробничої програми ресурсів (рис. 3).

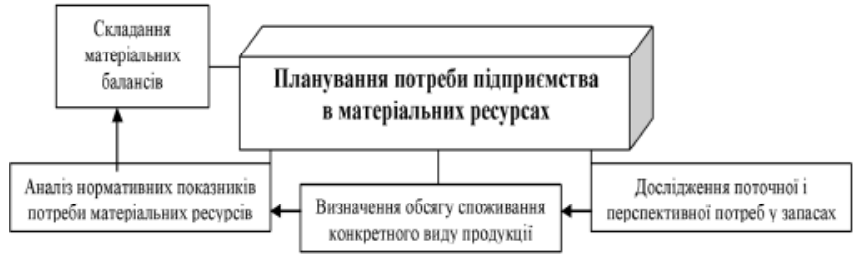

Рис. 3. Схема організації процесу планування потреби матеріальних ресурсів Джерело: розроблено автором.

Поточний облік процесів надходження виробничих запасів, їх видача у підрозділи та виявлення фактичної наявності й стану матеріальних ресурсів надають можливість: встановлювати наявність і напрями руху матеріальних ресурсів; забезпечити початкові дані для дієвого контролю за використанням і збереженням матеріальних ресурсів, виконанням замовлень запасів, дотриманням угод на постачання; здійснити аналіз та оцінювання ефективності використання виробничих запасів у будь-якій структурній ланці технологічного процесу, за кожним робочим місцем. Достовірне, точне і повне облікове забезпечення має супроводжувати кожен етап процесу матеріального забезпечення, сприяючи розробці, узгодженню та прийняттю ефективних управлінських рішень щодо використання запасів. Належна організація облікового процесу має забезпечити: надходження інформації про залишки і рух виробничих запасів у місцях їх використання й зберігання; оперативне документальне оформлення процесів постачання, використання й списання виробничих запасів; розрахунок первісної вартості матеріальних ресурсів, які надходять на підприємство; інформаційну базу для здійснення контрольних заходів за витрачанням сировини й матеріалів, порівняння з нормативами, нормами та затвердженими лімітами; отримання даних для перманентного контролю виконання укладених договорів за 
асортиментом, термінами постачання, якістю, відповідності договірних зобов'язань між контрагентами. Рис. 4 демонструє порядок здійснення поточного обліку та формування оперативних облікових даних на всіх етапах процесу матеріального забезпечення.

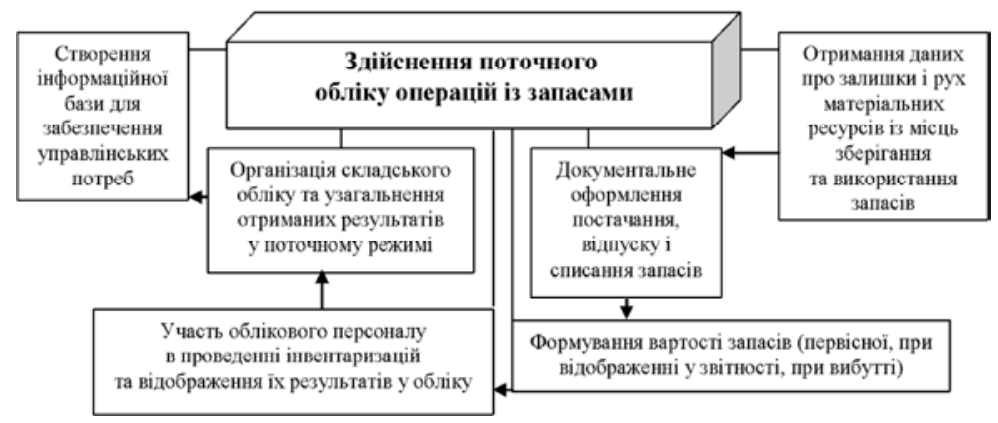

Рис. 4. Схема порядку поточного обліку надходження матеріальних ресурсів, їх переміщення і видачі підрозділам та виявлення фрактичного стану запасів Джерело: розроблено автором.

Контроль надходження, порядку збереження і схоронності, фрактичного стану та витрачання запасів у структурних підрозділах підприємства згідно з їх призначенням забезпечуються ефективною організацією нагляду, проведенням інвентаризацій і систематичним моніторингом на кожному з етапів процесу матеріального забезпечення. Вказані дії забезпечують раціональне використання виробничих запасів і $є$ важливим аспектом організації процесу матеріального забезпечення (рис. 5).

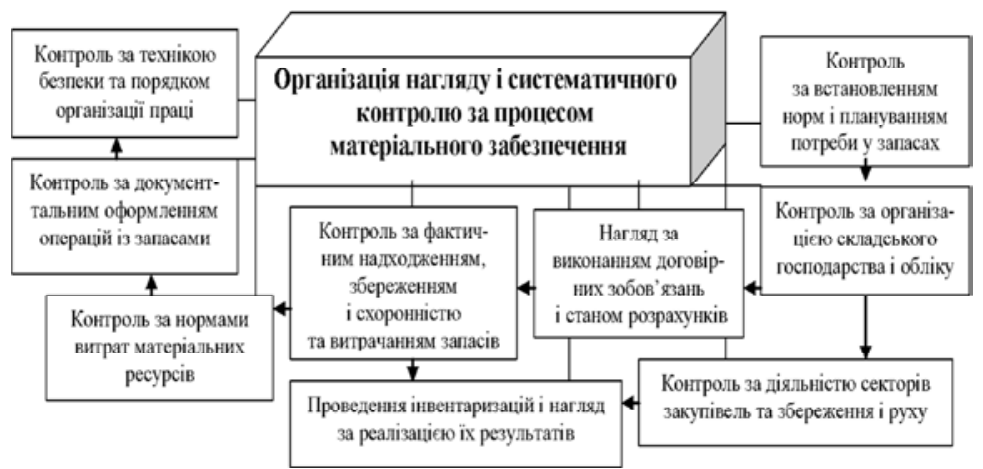

Рис. 5. Схема організації нагляду, інвентаризацій і систематичного контролю за процесом матеріального забезпечення

Джерело: розроблено автором.

Розробка заходів із раціональнішого використання виробничих запасів $€$ завершальним етапом процесу побудови оптимальної й ефективної системи матеріального забезпечення. Це передбачає: виявлення та мобілізацію резервів економії матеріальних ресурсів; упровадження у виробничий процес маловідходних і ресурсозберігаючих технологій; заміну дефіцитних видів запасів та використання 
відходів виробництва і вторинних ресурсів; організацію більш ефективних фрорм використання, збереження та доставки ресурсів. Доцільними будуть заходи із впровадження механізмів стимулювання для працівників, які раціоналізують усі етапи використання матеріальних ресурсів. Впроваджуючи заходи, що повинні сприяти більш ефективному використанню виробничих запасів, слід відстежувати, щоб вони в жодному разі не впливали негативно на якісні характеристики виробничого процесу та готової продукції. Порядок розроблення заходів із більш раціонального використання матеріальних ресурсів окреслено на рис. 6.

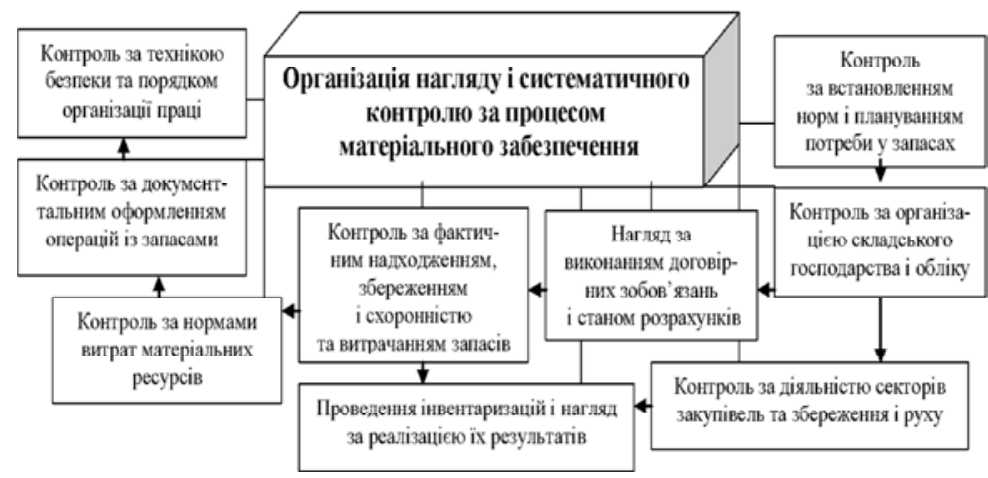

Рис. 6. Схема порядку розроблення заходів із більш раціонального використання матеріальних ресурсів

Джерело: розроблено автором.

Удосконалення організації процесу матеріального забезпечення задля інтеграції обліку з іншими функціями управління також потребує ефективної автоматизації в економічному секторі служби матеріального забезпечення у тому змісті, в якому їі розуміють прихильники централізації, що практично не залежить від фрорм організації обліку. Практика доводить, що на деяких підприємствах, які частково спробували децентралізувати облік (ПАТ «Кіровоградський хлібозавод»), рівень автоматизації облікового процесу значно вищий, ніж на тих підприємствах (ПАТ «Паляниця»), де переважним є принцип централізації обліку.

Такими вбачаються нам завдання ефективної діяльності служби матеріального забезпечення підприємств й алгоритм їх виконання в економічному секторі організаційної структури, що інтегрує інформаційні та оперативно-виробничі функції управління процесами матеріального забезпечення.

Удосконалення інтеграційних процесів між функціями управління відбувається у двох напрямках. 3 одного боку, оскільки спільним для всіх фінансових відділів $є$ сам процес матеріального забезпечення, то для досягнення загальної мети посилюється взаємозв'язок між бухгалтерами, плановиками, контролерами та економістами, які намагаються вирішувати завдання з більшою ефективністю, а з іншого - посилюється взаємозв'язок економічного сектору служби матеріального забезпечення з оперативновиробничим персоналом інших секторів (закупівель, зберігання і руху). Окремі працівники секторів (безпосередні виконавці) здійснюють функції обліку, планування, 
аналізу, контролю, що й приводить до оптимального співвідношення повноважень і відповідальності кожного.

Водночас «необхідне дотримання трьох особливостей бухгалтерського обліку як процесу. Перша особливість полягає у тому, що кожен господарський факт, явище або процес мають бути насамперед зафіксовані на носії як доказ, тобто як документ, що закріплено у відповідному законодавчому акті. Другою особливістю $є$ те, що всі господарські факти, явища та процеси з первинних документів, тобто доказів про їх реальність, підлягають обов'язковому запису (реєстрації) і нагромадженню в облікових регістрах. Це означає, що облікові регістри після того, як у них буде зроблено записи про відповідні господарські фракти й інші математичні процедури - додавання, віднімання та визначення нового стану об'єкта обліку, автоматично стають носіями облікової інформації. Третя особливість у тому, що облік як процес закінчується визначенням нового стану об'єкта в облікових реєстрах, а підсумкові дані необхідно перенести з облікових реєстрів у звітні форми, котрі після їх заповнення автоматично стають носіями облікової (підсумкової, звітної) інформації [3, с. 40]».

Висновки та перспективи подальших досліджень. Облік виявляє, вимірює, нагромаджує, реєструє, узагальнює, передає та зберігає дані про діяльність суб'єкта господарювання внутрішнім і зовнішнім користувачам для прийняття ефективних рішень, одночасно створюючи інформаційне середовище для інших функцій управління. 3 розвитком ринкових відносин облік набуває все більшого значення, методи його удосконалюються, а межі розширюються. Облік як засіб для планування, економічного аналізу, контролю, стимулювання, регулювання та узагальнення розподілу матеріальних ресурсів відіграє важливу роль у діяльності підприємств, а тому цілком закономірною і логічною є його інтеграція з іншими функціями управління.

Для вирішення основних завдань служби матеріального забезпечення в економічному секторі ми розробили та запропонували такі схеми: організації процесу встановлення норм матеріальних ресурсів; організації процесу планування потреби матеріальних ресурсів; порядку поточного обліку надходження матеріальних ресурсів, їх переміщення і видачі підрозділам та виявлення стану виробничих запасів; організації нагляду, інвентаризацій та перманентного контролю за процесами матеріального забезпечення; порядку розробки заходів із більш раціонального використання матеріальних ресурсів.

Вказані пропозиції містять авторське бачення напрямків удосконалення організації процесу матеріального забезпечення із встановленням конкретних завдань та з'ясуванням ролі, місця й зв'язку всіх управлінських функцій - обліку, планування, економічного аналізу, контролю, стимулювання та регулювання. Об'єктом наших майбутніх досліджень буде розробка рекомендацій з удосконалення системи матеріального забезпечення окремих підприємств різних сфер національної економіки із врахуванням впливу галузевих особливостей та специфіки виробничих процесів.

\section{תimepamypa}

1. Валуєв Б. І. Організаційні можливості поглиблення інтеграційних процесів в управлінні підприємством Наукові праці Кіровоградського державного технічного університету. Сер. : Економічні науки. 2003. Вип. 4. Ч. І. С. 17-22. 
2. Зарудна Н. Я. Облік і аналіз процесу постачання матеріальних цінностей : дис. ... канд. екон. наук : 08.00.09 / Терн. нац. екон. ун-т. Тернопіль, 2013. 215 с.

3. Пугаченко О. Б. Облік процесів матеріального забезпечення в системі управління хлібопекарними підприємствами : дис. ... канд. екон. наук : 08.00.09 / Кіровоград. нац. техн. ун-т. Кіровоград, 2008. 225 с.

4. Сиротенко Н. А. Функції обліку та контролю в системі управління матеріальним забезпеченням виробництва (на прикладі підприємств кондитерської галузі) : дис. ... канд. екон. наук : 08.00.09 / Одес. держ. екон. ун-т. Одеса, 2007. 385 с.

5. Шурупов Г. В. Механизм управления материальным обеспечением деятельности промышленных предприятий : дис. ... канд. екон. наук : 08.00.09/ Одес. гос. экон. ун-т. Одесса, 2004. 203 с.

6. Балашук Н. Напрями удосконалення матеріально-технічного забезпечення діяльності підприємств в умовах ресурсних обмежень. Сучасні підходи до управління підприємством : зб. VIII Всеукр. наук.-практ. конф. 2017. URL : http://conf.management.fmm.kpi.ua/proc/issue/view/5958 (дата звернення: 12.12.2019).

7. Гуржій Н. М., Бебешко І. С. Моніторинг системи матеріального забезпечення підприємств харчової промисловості. Вісник Чернівецького торговельноекономічний інститут Київського національного торговельно-економічного університету. Сер : Економічні науки. 2010. № 2. С. 74-80.

8. Гурин О. М. Методика формування раціональної структури системи матеріального забезпечення повітряного командування Повітряних Сил Збройних Сил України у повітряній операції. Збірник наукових праць Харківського національного університету Повітряних Сил. 2017. № 2 (51). C. 35-39.

9. Дмитрик М. М., Куліш О. І., Харіх О. Д. Облік процесів матеріального забезпечення у системі управління виробництва кондитерської продукції. Вісник Бердянського університету менеджменту і бізнесу. 2012. № 3 (19). C. 80-84.

10. Кивлюк В. С., Ганненко Ю. О. Удосконалення системи забезпечення матеріальними ресурсами Збройних Сил України. Social development \& Security. 2018. Вип. 2 (4). С. 49-58.

11. Майборода М. М. Вплив матеріально-технічного забезпечення на ефективність виробництва зерна. Вісник Харківського національного технічного університету сільського господарства імені Петра Василенка. 2016. Вип. 173. С. 132-137.

12. Розмислов О. М., Мартинов А. А. Аналітичне забезпечення стратегічного управління матеріальними витратами підприємства. Вісник Одеського національного університету. Сер. : Економіка. 2018. Т. 23. Вип. 4. С. 153-158.

13. Крушельницька О. В. Управління матеріальними ресурсами : навч. посібник. Київ : Кондор, 2003. 162 с. 


\section{References}

1. Valuiev, B.I. (2003). Orhanizatsiini mozhlyvosti pohlyblennia intehratsiinykh protsesiv v upravlinni pidpryiemstvom [Organizational enhancing integration processes in enterprise management]. Naukovi pratsi Kirovohradskoho derzhavnoho tekhnichnoho universytetu. Ekonomichni nauky - Proceedings Kirovograd State Technical University. Economics, 4, 17-22 [in Ukrainian].

2. Zarudna, N.la. (2013). Oblik i analiz protsesu postachannia materialnykh tsinnostei [Accounting and analysis of the supply of property] Candidate's thesis. Ternopil [in Ukrainian].

3. Puhachenko, O.B. (2008). Oblik protsesiv materialnoho zabezpechennia v systemi upravlinnia khlibopekarnymy pidpryiemstvamy [Accounting processes material support in the management of bakery enterprises] Candidate's thesis. Kirovohrad [in Ukrainian].

4. Syrotenko, N.A. (2007). Funktsii obliku ta kontroliu v systemi upravlinnia materialnym zabezpechenniam vyrobnytstva: na prykladi pidpryiemstv kondyterskoi haluzi [Accounting and control functions in the management of production material support: in the example of the confectionery industry] Candidate's thesis. Odessa [in Ukrainian].

5. Shurupov, G.V. (2004). Mehanizm upravlenija material'nym obespecheniem dejatel'nosti promyshlennyh predprijatij [The mechanism of control material support industrial activities] Candidate's thesis. Odessa [in Russian].

6. Balashuk, N. (2017) Napriamy udoskonalennia materialno-tekhnichnoho zabezpechennia diialnosti pidpryiemstv $v$ umovakh resursnykh obmezhen [Areas of improvement of logistical support of the activity of enterprises under conditions of resource limitations] Suchasni pidkhody do upravlinnia pidpryiemstvom : zb. VIII Vseukr. nauk.-prakt. konf. URL: http://conf.management.fmm.kpi.ua/proc/issue/ view/5958 (дата звернення: 12.12.2019) [in Ukrainian].

7. Hurzhii, N.M. \& Bebeshko, I.S. (2010). Monitorynh systemy materialnoho zabezpechennia pidpryiemstv kharchovoi promyslovosti [Monitoring system of material support of the food industry]. Visnyk Chernivetskoho torhovelnoekonomichnyi instytut Kyivskoho natsionalnoho torhovelno-ekonomichnoho universytetu. Ekonomichni nauky - Bulletin of Chernivtsi Trade and Economics Institute of the Kyiv National Trade and Economic University. Economics, 2, 74-80 [in Ukrainian].

8. Huryn, O.M. (2017) Metodyka formuvannia ratsionalnoi struktury systemy materialnoho zabezpechennia povitrianoho komanduvannia Povitrianykh Syl Zbroinykh Syl Ukrainy u povitrianii operatsii [Methods of formation of rational structure of material support system of air command of the Air Forces of Ukraine in air operation]. Zbirnyk naukovykh prats Kharkivskoho natsionalnoho universytetu Povitrianykh Syl, 2 (51), 35-39. [in Ukrainian].

9. Dmytryk, M.M., Kulish, O.I. \& Kharikh, O.D. (2012). Oblik protsesiv materialnoho zabezpechennia u systemi upravlinnia vyrobnytstva kondyterskoi produktsii [Accounting processes material support in the management of confectionery 
products]. Visnyk Berdianskoho universytetu menedzhmentu i biznesu - Bulletin Berdyansk University of Management and Business, 3 (19), 80-84 [in Ukrainian].

10. Kyvliuk, V.S., Hannenko, Yu.O. (2018) Udoskonalennia systemy zabezpechennia materialnymy resursamy Zbroinykh Syl Ukrainy [Improvement of the material resources system of the Armed Forces of Ukraine]. Social development \& Security. 2 (4). 49-58 [in Ukrainian].

11. Maiboroda, M.M. (2016) Vplyv materialno-tekhnichnoho zabezpechennia na efektyvnist vyrobnytstva zerna [Influence of logistical support on grain production efficiency]. Visnyk Kharkivskoho natsionalnoho tekhnichnoho universytetu silskoho hospodarstva imeni Petra Vasylenka, 173, 132-137 [in Ukrainian].

12. Rozmyslov, O.M., Martynov, A.A. (2018)Analitychne zabezpechennia stratehichnoho upravlinnia materialnymy vytratamy pidpryiemstva [Analytical support of strategic management of material costs of the enterprise]. Visnyk Odeskoho natsionalnoho universytetu. Seriia : Ekonomika, 23, 4. 153-158. [in Ukrainian].

13. Krushelnytska, O.V. (2003). Upravlinnia materialnymy resursamy [Material management]. Kyiv: Kondor [in Ukrainian].

Статтю отримано 21 січня 2020 р.

Article received January 21, 2020. 